G. Żywica, M. Luczak ${ }^{1}$

Institute of Fluid-Flow Machinery Polish Academy of Sciences, 80-952 Gdańsk, Fiszera 14 Street, Poland

${ }^{1}$ LMS International, Interleuvenlaan 68, B-3001 Leuven, Belgium

\title{
THE EXPERIMENTAL VERIFICATION OF THE NUMERICAL MODEL FOR CRACKED BEAM INCORPORATING MEASUREMENT UNCERTAINTY
}

\begin{abstract}
This paper presents verification of the numerical model of a cracked beam against the experimental results. Presented investigation assesses the adequacy of a crack model incorporated in the ABAQUS commercial FEM package. Structure under investigation is a square hollow steel section. Experimental and numerical modal model parameters like mode shapes and natural frequencies were compared. Obtained results confirm the high level of confidence for the numerical model of the crack. This observation constitutes application of crack model in the computations of more complex structures.
\end{abstract}

Key words: Modal analysis, Finite Element Method, experimental verification, measurement uncertainty

\section{INTRODUCTION}

Rapid advance in the computing technology results in widening of CAE techniques, machine operation and diagnostics of mechanical structures. Numbers of sophisticated software packages are available. Among them Finite Element Method (FEM) based are common. Many research centers and industrial companies are more and more intensively reducing time of the test shifting more preproduction prototyping from real into virtual world. Numerical models however need to be verified and validated such the results obtained need to be as close as possible to experimental data values $[11,14]$. In case of critical machinery direct verification of the model is very difficult. In particular it concerns cases of investigating defects which could have occurred during machine operation. Performing active diagnostic experiment is often hardly possible due to high costs and risk of the personnel's safety. In such cases the only solution is a partial model verification confronting numerical models of the structure with the experimental results.

In the following part of the paper experimental verification of the crack numerical modeling is discussed. Presented investigation were carried out to assess the reliability of a crack model incorporated in FEM based ABAQUS commercial suite $[1,13]$. Crack model applied in package was used for the extensive numerical simulations investigation of the supporting structure miscellaneous defects influence onto dynamic 
state of the rotating machinery $[15,16]$. Scope of this investigation included among others a crack of a bearing stand. Object of the investigation was a large test rig of a multi-supported rotating machine being a part of Vibro Diagnostics Laboratory in IFFM PASci. Verified numerical model of this test stand was presented in details in [14]. According to abovementioned reasons introduction of considered defects into support structure was not possible. Therefore separated numerical simulations were performed to verify the package intrinsic crack model. Afterwards the crack model will be applied for the numerical simulations of a large scale rotating machinery test rig.

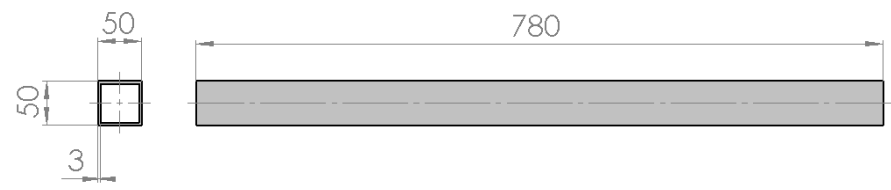

Fig. 1. Dimensions of the investigated beam

Due to specific operation of rotating machine verification analysis concerned only dynamic properties of the model. Natural frequencies and mode shapes estimated from test and simulation have been compared. Many scientific papers indicate the existence of a strong sensitivity of a structure's modal model to a discontinuity of the structure caused by a crack $[2,5,7]$. Object of the investigation is a square hollow steel section. Object of the investigation ensures that only the most important issues will be investigated. Basic dimensions of the investigated beam were presented in Fig. 1. Course of the experimental and numerical investigation are presented in following points.

\section{THEORETICAL MODAL ANALYSIS}

Investigated beam was modeled by means of FE method in Abaqus software [1]. Interface of this package is user-friendly and intuitive allowing better control of the work flow. Numerical model of the beam is presented in Fig. 2. In this figure the freefree support points and the crack localization are marked. In the model cubic finite element C3D20R was used. Mesh grid was optimised with criterion of efficiency and precision of the computations. Two crack depths were accounted $-25 \%$ and $50 \%$ of the height of beam transverse cross section. For the crack model the option "Crack-Assign Seam" was used which refers to a model of permanently open crack. For each of considered variants computed were eigenfrequencies and eigenvectors. The upper limit of the bandwidth of interest was set to $2500 \mathrm{~Hz}$. 


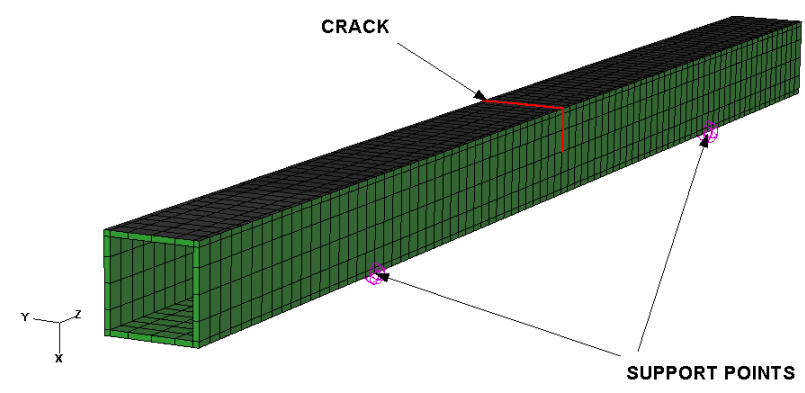

Fig. 2. FEM model of the investigated beam

The FE model of a beam was developed in non-deterministic manner. Due to a lack of knowledge uncertainties of model parameters were defined. Uncertain parameters were Young modulus and density. These two parameters were chosen due to the unknown steel type the specimen was made of. In the real life engineering practice values of some model parameters are not precisely known and are assumed approximate. Except the material properties the source of model uncertainties could be geometry of an object. In case of the large sized parts the dimension variation can be significant for two nominally identical items. This is due to different tolerance values defined, manufacturing errors, wear of machining tools, inhomogeneous mass distribution leading to local stiffness variation to name some of them. Differences in the geometrical constraints of the real structure and its numerical model lead therefore to discrepancies of the experimental and computational results.

The abovementioned factors were accounted in the investigated non-deterministic FE model. Uncertain parameters were defined by means of intervals of its possible values. Parameter variability was set to $\pm 5 \%$ of the nominal values. Nominal values of the parameters are given in the material properties data sheets for the widely used construction steel [9]. These nominal values are respectively $\rho=7800 \mathrm{~kg} / \mathrm{m}^{3}$ and $\mathrm{E}=2,1 \cdot 10^{11} \mathrm{~Pa}$. Eigenfrequency values computed for the investigated beam for the parameters nominal values are presented in Table 1.

Table 1. Computed eigenfrequency (values in $\mathrm{Hz}$ )

\begin{tabular}{|c|c|c|c|c|}
\hline No. & No crack & Crack 25\% & Crack 50\% & $\begin{array}{c}\text { Mode shape } \\
\text { description }\end{array}$ \\
\hline 1 & 488 & 428 & 342 & First bending(x) \\
\hline 2 & 488 & 473 & 437 & First bending (y) \\
\hline 3 & 1263 & 1262 & 1260 & Second bending (x) \\
\hline 4 & 1263 & 1426 & 1366 & Second bending (y) \\
\hline 5 & 2255 & 2098 & 1901 & Third bending (x) \\
\hline 6 & 2255 & 2209 & 2117 & Third bending (y) \\
\hline 7 & 1683 & 1084 & 742 & First torsional \\
\hline
\end{tabular}

Table 1 contains only the frequencies related to most representative mode shapes present within the investigated bandwidth. Mode shapes plots are given in further part of this paper which refers to a model verification \& validation. 


\section{EXPERIMENTAL MODAL ANALYSIS (EMA)}

EMA is a validated and commonly applied tool for widespread structural dynamics identification and vibration related problems. Result of the modal experiment is an estimation of modal model parameters, namely natural frequencies, damping ratios and mode shapes [11]. Crack occurring within the structure causes local stiffness reduction which influences the overall system dynamics. Based on this phenomenon some crack detection methods were developed. A research field denoted as Structural Health Monitoring is currently gaining international exposure in conferences and scientific journals $[2,3,5,12]$. Damage detection in structures plays an extremely important role in technical diagnostics.

Experimental investigation was made by means of dedicated LMS hardware-software system. It comprises of signal acquisition SCADAS III frontend and Test.Lab software governing the workflow. Object of the investigation was fixed on the test stand in freefree boundary conditions provided by an elastic rubber cords. 36 evenly spaced measurement points grid was defined on the beam for the location of triaxial accelerometers. Structure was excided by means of impact of a modal hammer weighting $0,16[\mathrm{~kg}]$. Five measurements were done for each of three beam crack configurations $(0 \%, 25 \%$ and $50 \%)$. Excitation was applied in vertical and horizontal direction. The total number of measurement was 30. Estimated results were subject of the statistical analysis [10]. For each of the natural frequencies the mean value and standard deviation. Results of these calculations are presented in Table 2. Measurement error for individual mode shapes computed as a standard deviation did not exceeded $3 \%$.

Table 2. Experimental natural frequencies (values in $\mathrm{Hz}$ )

\begin{tabular}{|c|c|c|c|c|}
\hline No. & No crack & Crack 25\% & Crack 50\% & $\begin{array}{c}\text { Mode shape } \\
\text { description }\end{array}$ \\
\hline 1 & 480 & 416 & 329 & First bending(x) \\
\hline 2 & 482 & 464 & 429 & First bending (y) \\
\hline 3 & 1248 & 1241 & 1238 & Second bending (x) \\
\hline 4 & 1227 & 1391 & 1341 & Second bending (y) \\
\hline 5 & 2275 & 2095 & 1894 & Third bending (x) \\
\hline 6 & 2185 & 2221 & 2106 & Third bending (y) \\
\hline 7 & 1644 & 1001 & 730 & First torsional \\
\hline
\end{tabular}

The important remark to be made here is that the experimental modal model parameters are affected by number of factors. In the presented investigation these are the excitation method and point, mass and mounting technique for the accelerometers, damping and stiffness characteristics of the supporting rubber cords, supporting points of the structure, environmental factors like temperature, signal noise level and many others. Differences in between individual measurements are not only expected but also inevitable. 


\section{VERIFICATION RESULTS}

This section of the paper presents the comparison of the experimental and numerical results. As it was stated in the introduction such comparison of real test against computation results allows assessing the validation level of the model. Experimental numerical modal models correlation analysis was done by means of evaluation of natural frequencies differences and visual inspection of the estimated mode shapes.
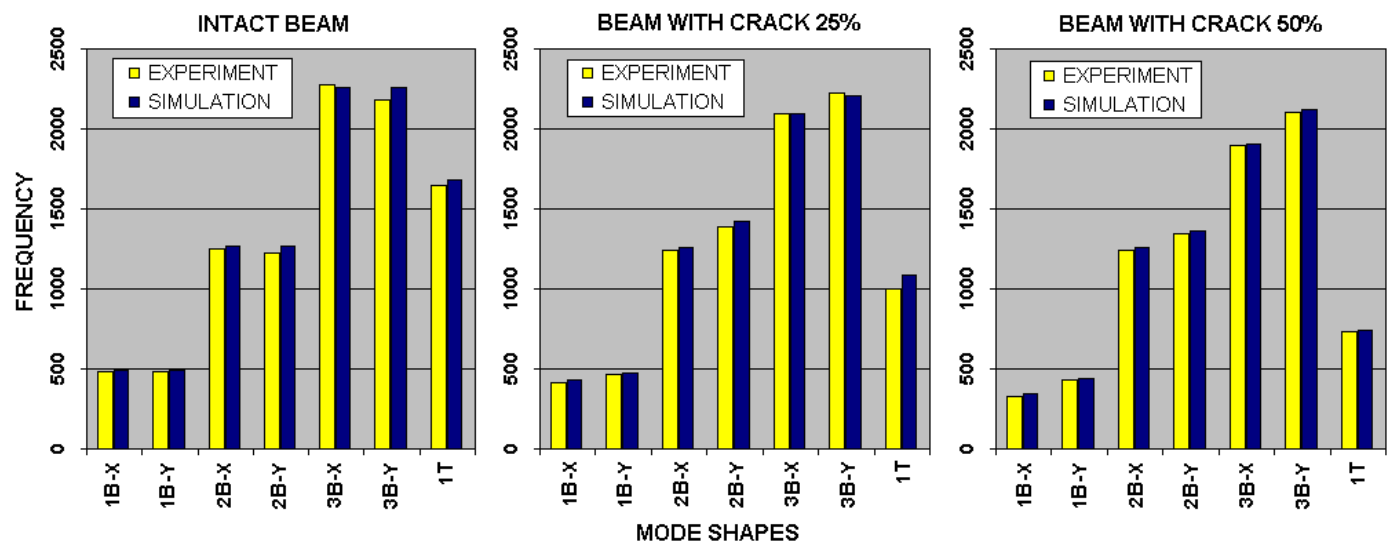

Fig. 3. Comparison of the natural frequencies estimated from a simulation and test

Fig. 3 presents natural frequencies of the most representative mode shapes present in the frequency range up to $2500 \mathrm{~Hz}$. Natural frequency values were presented for the intact beam and with presence of $25 \%$ and $50 \%$ crack. Presented charts clearly confirm high level of numerical and experimental results correspondence. Natural frequencies of both computational and test results were consistent within investigated bandwidth even in case of accounting for the test data variability and numerical model parameters uncertainties. Fig. 4 and Fig. 5 present mode shapes plots. These mode shapes were most sensitive for the crack appearance. Frequencies of those mode shapes changed most in presence of crack. Results of the other research reported in scientific papers had not included the torsional mode shapes. This is due to a difficulty of excitation and measurement of torsional vibration form. Presented investigations clearly indicate that the torsional mode shape is most sensitive for applied crack configuration (location and size). For the crack value of $50 \%$ of the beam cross section the corresponding value of the natural frequency decreased by more than $50 \%$.

On the contrary it was possible to identify the less sensitive mode shape. This less sensitive mode shape is a second bending form. This observation is confirmed in both numerical and experimental results. This phenomenon can be explained by a fact that for the second bending mode shape crack is located in the node of the mode and therefore its contribution to overall structure response is relatively small.

Experimental mode shapes presented in the Fig. 4 and Fig. 5 were far more difficult to identify than the numerical ones. This is well recognized problem. In presented case the mass loading effect of the accelerometers was important. Further increase of the crack would introduce even more complex situation because of coupling of the modes. Example of the double mode is presented on the plot of the intact beam first bending mode. This is due to a geometrical symmetry of the beam cross section. Presence of the 
coupled or double modes is making the assessment of the experimental modal models even mode difficult.

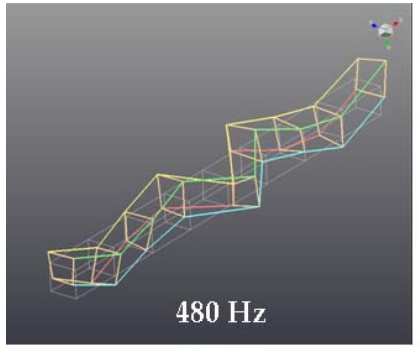

$488 \mathrm{~Hz}$

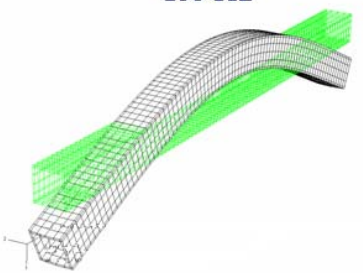

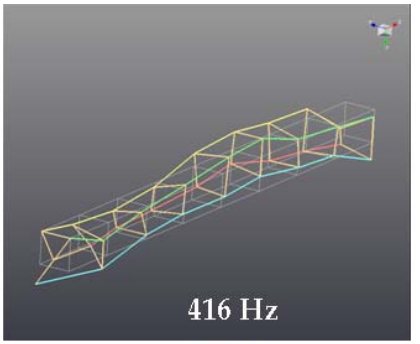

$428 \mathrm{~Hz}$

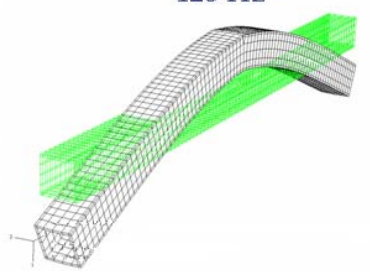

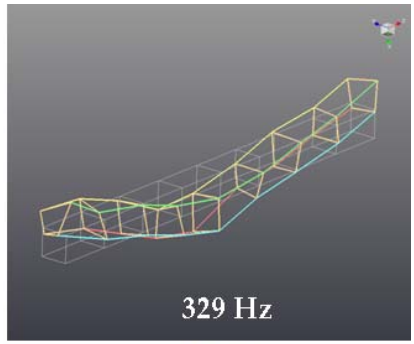

$342 \mathrm{~Hz}$

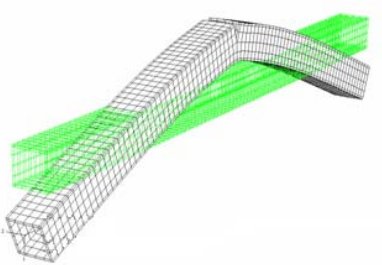

Fig. 4. Experimental and numerical results comparison for the first bending mode shape in vertical direction (no crack, crack $25 \%$ and crack $50 \%$ )

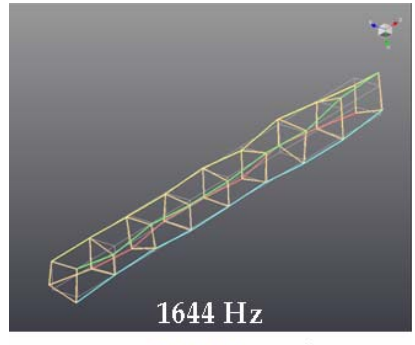

$1683 \mathrm{~Hz}$

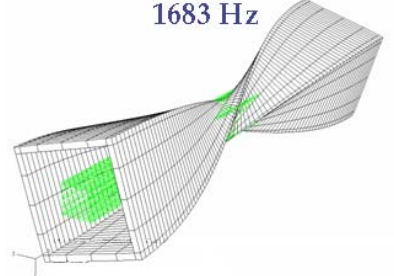

Fig. 5. Experimental and numerical results comparison for the first torsional mode shape (no crack, crack $25 \%$ and crack $50 \%$ )

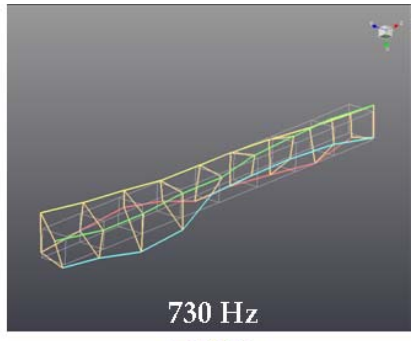

$742 \mathrm{~Hz}$
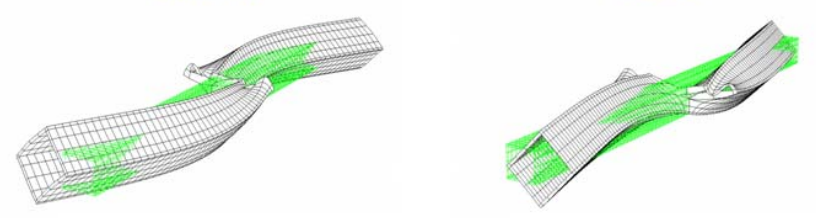

SUMMARY AND CONCLUSIONS

This paper presents verification of the cracked beam FEM model. The research was performed to validate the crack model implemented in the commercial FEM software. Modal model parameter observation will be applied in the mixed numerical and experimental investigations of a large scale rotating machinery test rig. On this rig it was not possible to introduce a real crack therefore crack model validation was done for the beam.

Obtained results confirmed applicability of the implemented crack model. Discrepancies in the numerical simulation and experimental results did not exceed 
couple percent. For all investigated cases high accordance level between model and test was achieved. Due to complexity of the research subject and methodology the estimated results can be found adequate.

\section{REFERENCES}

1. ABAQUS Analysis User's Manual, Volume II, III, IV, V. Version 6.5. ABAQUS, Inc. 2004.

2. Gounaris G.D., Papadopoulos C.A.: Crack Identification in Rotating Shafts by Coupled Response Measurements. Engineering Fracture Mechanics 69 (2002) 339352.

3. Kiciński J.: Rotor Dynamics. IFFM Publishers, Gdańsk, 2006.

4. Kiciński J. [ed.]: Symulacja defektów i budowa relacji diagnostycznych modelu numerycznego. Wyd. Politechniki Śląskiej, Gliwice, 2005.

5. Kim J.T., Stubbs N.: Crack Detection in Beam-Type Structures Using Frequency Data. Journal of Sound and Vibration 259(1) (2003) 145-160.

6. Lisowski W., Uhl T.: Komputerowe wspomaganie analizy korelacji eksperymentalnych modeli modalnych i modeli elementów skończonych. Konf. Metody i Systemy Komputerowe w Badaniach Naukowych i Projektowaniu Inżynierskim. AGH, Kraków (1999) 669-674.

7. Majkut L.: Symptomy drganiowe pęknięcia belki. Konf. WIBROTECH 2006, AGH, Kraków, 2006.

8. Neimitz A.: Mechanika pękania. PWN, Warszawa, 1998.

9. Niezgodziński M.E., Niezgodziński T., Wzory, wykresy i tablice wytrzymałościowe. PWN, Warszawa, 1977.

10. Plucińska A., Pluciński E.: Probabilistyka, rachunek prawdopodobieństwa, statystyka matematyczna, procesy stochastyczne. WNT, Warszawa, 2006.

11. Uhl T.: Komputerowo wspomagana identyfikacja modeli konstrukcji mechanicznych. WNT, Warszawa, 1997.

12. Vanlanduit S. et al.: Combined damage detection techniques. Journal of Sound and Vibration 266 (2003) 815-831.

13.Zienkiewicz O.C., Taylor R.L.: Finite Element Method. Vol. 1, 2. ButterworthHeinemann Publishers, Oxford, 2000.

14. Żywica G., Rybczyński J.: Identyfikacja modelu konstrukcji podpierającej maszyny wirnikowej. Diagnostyka 4(40) (2006) 71-76.

15. Żywica G.: Symulacyjne badanie wpływu pęknięcia konstrukcji podpierającej na stan dynamiczny łożyskowanego ślizgowo wirnika. Tribologia 1 (2007) 299-309.

16. Żywica G.: Wpływ pęknięcia na własności dynamiczne konstrukcji podpierającej wirnik. Wybrane zagadnienia analizy modalnej konstrukcji mechanicznych. Uhl T. [ed.], AGH, Kraków (2006) 246-254. 